\begin{tabular}{r|l|l|l}
$\begin{array}{c}\text { Case Reports in } \\
\text { Gastroenterology }\end{array}$ & $\begin{array}{l}\text { Case Rep Gastroenterol 2010;4:318-322 } \\
\text { DOl: 10.1159/000320590 }\end{array}$ & $\begin{array}{l}\text { Published online: } \\
\text { September 11, 2010 }\end{array}$ & $\begin{array}{l}\text { O 2010 S. Karger AG, Basel } \\
\text { ISSN 1662-0631 } \\
\text { www.karger.com/crg }\end{array}$ \\
\hline
\end{tabular}

This is an Open Access article licensed under the terms of the Creative Commons AttributionNonCommercial-NoDerivs 3.0 License (www.karger.com/OA-license), applicable to the online version of the article only. Distribution for non-commercial purposes only.

\title{
Idiopathic Retroperitoneal Hematoma
}

\author{
Tomoyuki Abe Masanori Kai Osamu Miyoshi \\ Takashi Nagaie \\ Department of Surgery, lizuka Hospital, lizuka, Japan
}

\section{Key Words}

Retroperitoneal cystic tumor · Idiopathic hematoma · Chronic expanding hematoma

\begin{abstract}
A 34-year-old female presented with sudden onset of severe abdominal pain in a flank distribution. A large mass was palpable in the right upper quadrant on physical examination. Abdominal contrast-enhanced computed tomography showed a well-defined, right-sided, retroperitoneal cystic lesion located between the abdominal aorta and the inferior vena cava (IVC). The tumor size was $55 \times 58 \mathrm{~mm}$, and it compressed the gallbladder and the duodenum. Upper gastrointestinal radiography revealed a stricture of the second portion of the duodenum by the tumor. T2-weighted magnetic resonance imaging showed that the whole part was hyperintense with hypointense rims, but the inner was partially hypointense. Based on the radiological findings, the preoperative differential diagnosis included retroperitoneal teratoma, Schwannoma, abscess, and primary retroperitoneal tumor. On laparotomy, the tumor was located in the right retroperitoneal cavity. Kocher maneuver and medial visceral rotation, which consists of medial reflection of the upper part of right colon and duodenum by incising their lateral peritoneal attachments, were performed. Although a slight adhesion to the IVC was detected, the tumor was removed safely. Thin-section histopathology examination detected neither tumor tissues nor any tissues such as adrenal gland, ovarian tissue, or endometrial implants. The final pathological diagnosis was idiopathic retroperitoneal hematoma; the origin of the bleeding was unclear. The patient was discharged without any complication 5 days after the operation.
\end{abstract}

\section{Introduction}

The common causes for retroperitoneal hemorrhage can be classified into two types: (1) external injury and (2) internal disease, such as abdominal aortic or visceral artery aneurysms, or after acute or chronic anticoagulation or fibrinolytic therapy [1]. Acute abdominal or flank pain, hypotension, and anemia [2-6] are the typical clinical characteristics of retroperitoneal hemorrhage. The clinical manifestations of 


\begin{tabular}{r|l|l|l}
$\begin{array}{c}\text { Case Reports in } \\
\text { Gastruanteriology }\end{array}$ & $\begin{array}{l}\text { Case Rep Gastroenterol 2010;4:318-322 } \\
\text { DOI: 10.1159/000320590 }\end{array}$ & $\begin{array}{l}\text { Published online: } \\
\text { September 11, 2010 }\end{array}$ & $\begin{array}{l}\text { O 2010 S. Karger AG, Basel } \\
\text { ISSN 1662-0631 } \\
\text { www.karger.com/crg }\end{array}$ \\
\hline
\end{tabular}

retroperitoneal hematoma vary and probably depend on the amount of hemorrhage, its effect on hemodynamics, the rate of onset of the hemorrhage (sudden or gradual), and the ability of the surrounding structures to contain the hemostatic system. Acute retroperitoneal hemorrhage can cause intra-abdominal hemoperitoneum that can be fatal, so emergent surgery is required. The strategy for retroperitoneal hematoma depends on the vital signs and the cause of the hemorrhage. Chronic hematoma is mostly removed at operation or by tube drainage; its prognosis appears to be better than that of the acute type. A hematoma can be imaged and its age can be determined with magnetic resonance imaging with a combination of T1 and T2 weighting [7].

Idiopathic retroperitoneal hematoma, so-called chronic hematoma, is relatively rare. Only a few cases of idiopathic retroperitoneal hematoma have been reported [1-6, 8-10]. A rare clinical case is reported, and a review of the relevant literature is presented.

\section{Case Report}

A 34-year-old woman was admitted to our hospital with acute abdominal and flank pain associated with vomiting in August 2009. Her medical history included no anticoagulant therapy, no abdominal trauma, and no specific systemic disease. Other than the large palpable mass in the right upper quadrant, results of physical examination were unremarkable. Her vital signs and laboratory data, including tumor makers, were within the normal range.

Abdominal computed tomography (CT) demonstrated a large, encapsulated, cystic tumor located behind the head of the pancreas, which was located between the inferior vena cava (IVC) and the aorta. The tumor compressed the second portion of the duodenum and the gallbladder (fig. 1a). No liver metastasis or lymph node swelling was detected. The tumor consisted of a small part of adipose tissue, without any calcification or soft tissue. The right renal vein was shifted up by the tumor. There were no abnormalities in either the abdominal aorta or its branches. T2-weighted magnetic resonance imaging (MRI) revealed a large tumor with hypointense rims, and the inner aspect was predominantly hyperintense. There was a partially hypointense lesion, which was suspected to be adipose tissue or old hematoma (fig. 1b). Upper gastrointestinal radiography showed compression of the second portion of the duodenum, which was shifted to the outer side by the tumor (fig. 1c). Based on the radiological findings, the preoperative differential diagnosis included teratoma, Schwannoma, abscess, other primary retroperitoneal tumor, or adrenal hematoma. On laparotomy, the extended Kocher maneuver, with right-sided medial visceral rotation that consists of medial reflection of the upper part of the right colon and duodenum by incising their lateral peritoneal attachments, was performed. The tumor was round, hard, and cystic, and was located between the IVC and the aorta (fig. 2). There was no invasion of any tissues, such as gallbladder and pancreas, but a slight adhesion to the IVC was detected. The tumor was safely resected. The operation time was $2 \mathrm{~h}$ and $25 \mathrm{~min}$. Blood loss was $250 \mathrm{ml}$.

On macroscopic examination, the specimen was an encapsulated, elastic hard, yellowish tumor, $55 \times 58 \mathrm{~mm}$ in size (fig. 3a). Microscopically, the tumor was encapsulated by thin fibrous tissue. The inside was filled with fibrin-like acidophilic cytoplasm, red blood cells, and foam cells, which consisted of fibrinoid exudates and mainly old hematoma (fig. 3b). Thin-section histopathology examination detected neither tumor tissue nor malignancy in other tissues such as the adrenal gland, ovarian tissue, or endometrial implants. The final pathological diagnosis was idiopathic retroperitoneal hematoma. The patient was discharged without any complication 5 days after the operation.

\section{Discussion}

Idiopathic retroperitoneal hemorrhage was first presented in 1909 and named 'abdominal apoplexy' [1]. The clinical symptoms and the radiological findings differed between the acute and the chronic type. Urgent treatment is necessary after adequate resuscitation because the hemorrhage can cause intra-abdominal hemoperitoneum in the 
acute type. Browne and Glashan [11] reported that failure to identify the site of bleeding in all three cases and early postoperative bleeding resulted in the death of two of three cases. They demonstrated the importance of surgical exploration and confirmed the high mortality rate of this condition. The chronic type was not lethal: the patient was stable, as was the hematoma. The precise treatment was not established, but surgical exploration was recommended from the view of curability, because delayed stenosis of the duodenum was reported [9].

Injury or rupture of the splanchnic vessels and an eroding primary or secondary tumor of the liver or kidneys [2] are the general causes of retroperitoneal hemorrhage (primarily vascular hemorrhage). Hepatocellular carcinoma and renal cell carcinoma are known for spontaneous hemorrhage into the peritoneal cavity. Ovarian tumors, endometrial implants, or ectopic tissues may cause spontaneous retroperitoneal hemorrhage. Kobayashi et al. [12] reported a case of unilateral adrenal hematoma, whose radiological findings were similar to our case. Spontaneous or idiopathic adrenal hematoma is also extremely rare, since most adrenal hematoma cases occur in association with trauma or similar causes of idiopathic retroperitoneal hematoma. To establish the preoperative diagnosis is difficult because of the rarity of this disease and its non-typical clinical appearance. Idiopathic retroperitoneal hematoma is rare. In particular, chronic idiopathic retroperitoneal hematoma is quite rare. Only a few cases have been reported [1-6, 8-10]. Nair and colleagues reported a case of a large asymptomatic retroperitoneal mass, suggesting a small leakage of blood over a considerable time, as in our case $[5,8]$.

Magnetic resonance images play a more useful role in making the diagnosis of hematoma than CT by distinguishing between a collection of fluid such as blood and a neoplasm, such as pheochromocytoma or carcinoma [13]. Three types were classified based on duration: the acute stage (less than 7 days after onset); the subacute stage ( 7 days to 7 weeks after onset), and the chronic stage (which typically begins 7 weeks after onset). In the chronic stage, as in the present case, a hypointense rim is present on $\mathrm{T} 1$ - and T2-weighted images due to preferential T2 proton relaxation enhancement, which is attributed to hemosiderin deposition and the presence of a fibrous capsule [7]. With this classification, our magnetic resonance image showed a chronic stage hematoma.

Microscopically, no neoplastic lesion, such as adenoma, carcinoma, pheochromocytoma, or hemangioma, was detected in the adrenal gland and ectopic ovarian tissue. On laparotomy, no abnormal vessels to the hematoma were detected, so the origin of the hemorrhage was unclear. Thin-section histopathology examination also provided no clues to the origin of the hemorrhage.

In conclusion, it is difficult to make a precise preoperative diagnose of idiopathic retroperitoneal hematoma or hemorrhage if the entity is not suspected. T1- and T2-weighted magnetic resonance images can be useful. Differentiation of this rare entity from an unknown retroperitoneal tumor should be considered. 


\begin{tabular}{r|l|l|l}
$\begin{array}{r}\text { Case Reports in } \\
\text { Gastroanterology }\end{array}$ & $\begin{array}{l}\text { Case Rep Gastroenterol 2010;4:318-322 } \\
\text { DOl: 10.1159/000320590 }\end{array}$ & $\begin{array}{l}\text { Published online: } \\
\text { September 11, 2010 }\end{array}$ & $\begin{array}{l}\text { I 2010 S. Karger AG, Basel } \\
\text { ISSN 1662-0631 } \\
\text { www.karger.com/crg }\end{array}$ \\
\hline
\end{tabular}
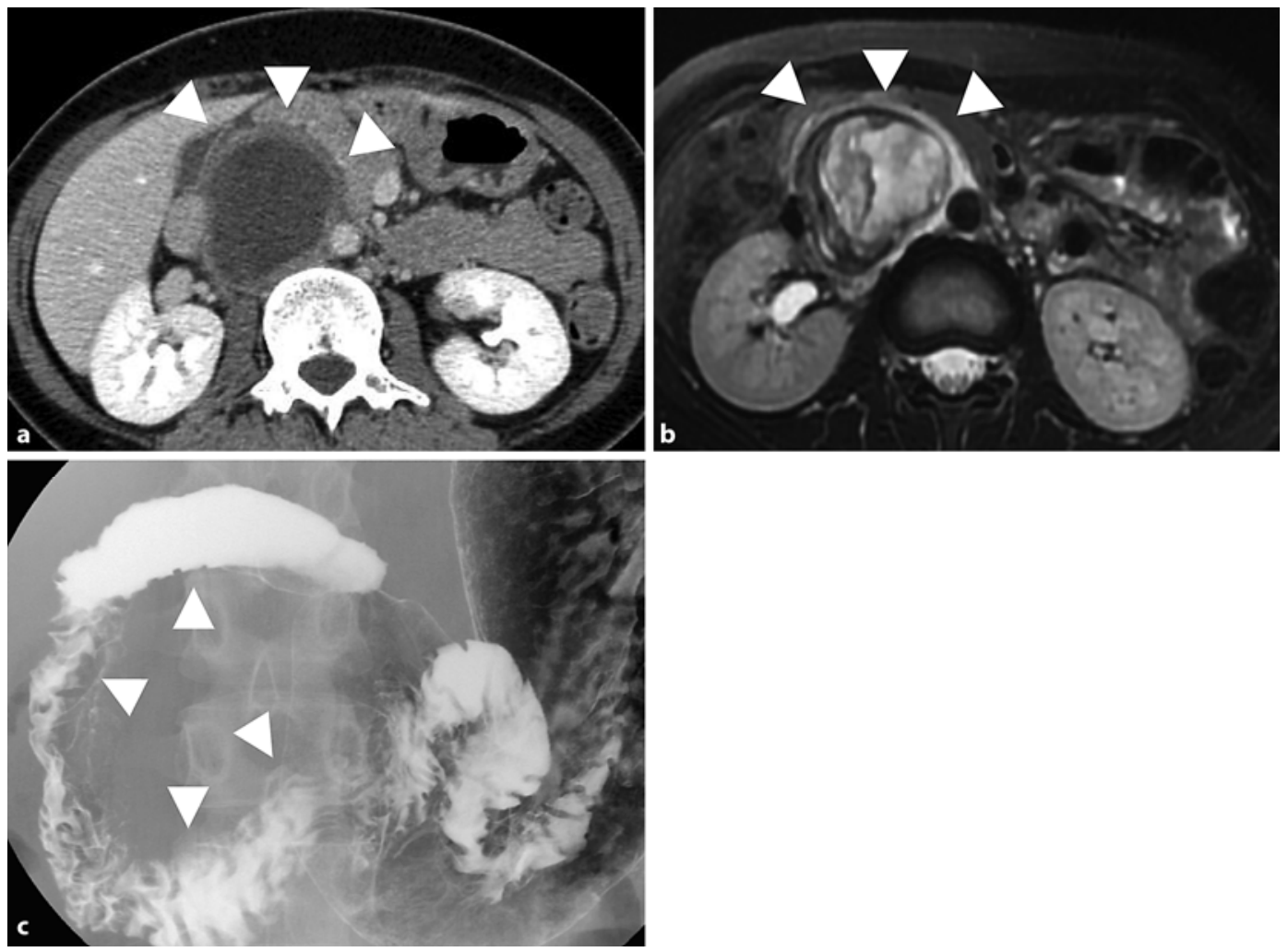

Fig. 1. a CT showed the round, encapsulated, cystic tumor located behind the head of the pancreas. The second portion of the duodenum and gallbladder were compressed. No invasion towards the surrounding tissues was detected (arrowheads). b T2-weighted MRI revealed that the tumor was encapsulated with hypointense rims, and the inner lesion had a partially hypointense lesion as a mosaic pattern (arrowheads). c Upper gastrointestinal radiography showed a slight stricture of the second portion of the duodenum, which was shifted to the outside by the tumor (arrowheads).

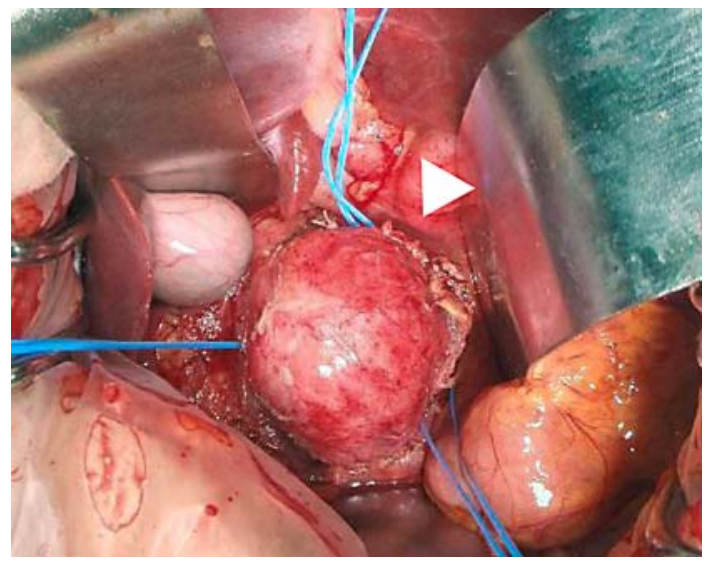

Fig. 2. On laparotomy, there was no invasion of the other organs, but a slight adhesion to the IVC was detected. An abnormal artery from the tumor to the aorta and the branches was not visible. 


\begin{tabular}{r|l|l|l} 
Case Reports in & $\begin{array}{l}\text { Case Rep Gastroenterol 2010;4:318-322 } \\
\text { DOI: 10.1159/000320590 }\end{array}$ & $\begin{array}{l}\text { Published online: } \\
\text { September 11, 2010 }\end{array}$ & $\begin{array}{l}\odot \text { 2010 S. Karger AG, Basel } \\
\text { ISSN 1662-0631 } \\
\text { www.karger.com/crg }\end{array}$ \\
\hline
\end{tabular}
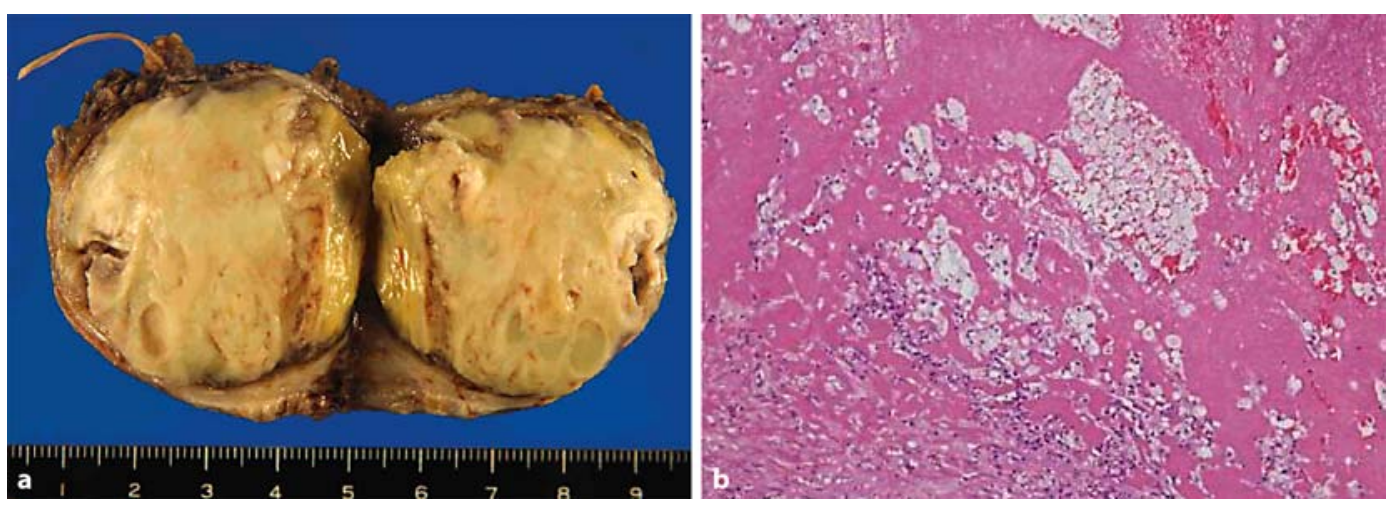

Fig. 3. a The cut surface of the specimen, $55 \times 58 \mathrm{~mm}$ in size, consisted mainly of whitish, solid parts. b Histopathological findings of the tumor showed that the inside was filled with fibrin-like acidophilic cytoplasm, red blood cells, and foam cells, which consisted of fibrinoid exudates and mainly old hematoma (hematoxylin and eosin staining, $\times 200$ ).

\section{References}

1 Henao F, Aldrete JS, Alabama B: Retroperitoneal hematoma of traumatic origin. Surg Gynecol Obstet 1985;161:106-116.

-2 Swift DL, Lingeman JE, Baum WC: Spontaneous retroperitoneal hemorrhage - a diagnostic challenge. J Urol 1980;123:577-582.

-3 Block M, Davis TE, Wolberg W: Spontaneous retroperitoneal hemorrhage - a case report. J Surg Oncol 1982;21:27-29.

-4 Rapp N, Audibert G, Gerbaud PF, Grosdidier G, Laxenaire MC: Spontaneous retroperitoneal hematoma: a rare cause of hemorrhagic shock. Ann Fr Anesth Reanim 1994;13:853-856.

5 Nair HT, Dolphin JM: Idiopathic retroperitoneal haemorrhage. Br J Clin Pract 1990;44:733-734.

6 Carr SR, Dinsmore RC, Wilkinson NW: Idiopathic spontaneous intraperitoneal hemorrhage: a clinical update on abdominal apoplexy in the year 2001. Am Surg 2001;67:374-376.

7 Kawashima A, Sandler M, Ernst D, Takahashi N, Roubidoux MA, Goldman SM, Fishman EK, Dunnick NR: Imaging of nontraumatic hemorrhage of the adrenal gland. Radiographics 1999;19:949-963.

$>8$ Nair HT, Muscroft TJ: Idiopathic retroperitoneal hematoma. Br J Clin Pract 1992;46:148.

9 Suzuki N, Nakao K, Narita K, Yamazaki K, Tanaka H, Matsuda K, Tsunoda A, Kusano M: A case of retroperitoneal hematoma of unknown cause (in Japanese). Jpn J Gastroenterol Surg 2006;39:358-362.

10 Matsuyama T, Nakatsuka H, Asahara T: Idiopathic retroperitoneal hematoma presenting as acute abdomen. Hiroshima J Med Sci 1986;35:223-226.

11 Browne MK, Glashan RW: Abdominal apoplexy. Br J Surg 1965;52:362-367.

12 Kobayashi T, Uenoyama S, Miura K, Takehara Y: Idiopathic unilateral adrenal hematoma: report of a case. Surg Today 2004;34:279-282.

13 Hoeffel C, Legmann P, Luton JP, Chapuis Y, Fayet-Bonnin P: Spontaneous unilateral adrenal hemorrhage: computerized tomography and magnetic resonance imaging findings in 8 cases. J Urol 1995;154:1647-1651. 